\title{
Fine scale gene flow and individual movements among subpopulations of Centrolene prosoblepon (Anura: Centrolenidae)
}

\author{
Jeanne M. Robertson ${ }^{1,2}$, Karen R. Lips ${ }^{1}$ \& Edward J. Heist ${ }^{1,3}$ \\ 1 Department of Zoology, Southern Illinois University, Carbondale, IL, 62901, USA. \\ 2 E145 Corson Hall, Department of Ecology and Evolutionary Biology, Cornell University, Ithaca, NY, 14850, USA; \\ jmr79@cornell.edu \\ 3 Fisheries and Illinois Aquaculture Center, Southern Illinois University, Carbondale, IL, 62901, USA.
}

Received 03-III-2006. Corrected 30-IV-2007. Accepted 14-V-2007.

\begin{abstract}
Dispersal capabilities determine and maintain local gene flow, and this has implications for population persistence and/or recolonization following environmental perturbations (natural or anthropogenic), disease outbreaks, or other demographic collapses. To predict recolonization and understand dispersal capacity in a stream-breeding frog, we examined individual movement patterns and gene flow among four subpopulations of the Neotropical glassfrog, Centrolene prosoblepon, at a mid-elevation cloud forest site at El Copé, Panama. We measured male movement directly during a two year mark-recapture study, and indirectly with gene flow estimates from mitochondrial DNA sequences (mtDNA). Individuals of this species showed strong site fidelity: over two years, male frogs in all four headwater streams moved very little (mean $=2.33 \mathrm{~m}$; mode $=0 \mathrm{~m}$ ). Nine individuals changed streams within one or two years, moving 675-1 $108 \mathrm{~m}$. For those males moving more than $10 \mathrm{~m}$, movement was biased upstream $(\mathrm{p}<0.001)$. Using mtDNA ND1 gene sequences, we quantified gene flow within and among headwater streams at two spatial scales: among headwater streams within two adjacent watersheds $\left(2.5 \mathrm{~km}^{2}\right)$ and among streams within a longitudinal gradient covering $5.0 \mathrm{~km}^{2}$. We found high gene flow among headwater streams $\left(\phi_{\mathrm{ST}}=0.007, \mathrm{p}=0.325\right)$ but gene flow was more limited across greater distances $\left(\phi_{\mathrm{CT}}=0.322, \mathrm{p}=0.065\right)$, even within the same drainage network. Lowland populations of $C$. prosoblepon potentially act as an important source of colonists for upland populations in this watershed. Rev. Biol. Trop. 56 (1): 13-26. Epub 2008 March 31.
\end{abstract}

Key words: Centrolenidae, dispersal, gene flow, mark-recapture, mitochondrial DNA, Neotropical.

Semi-isolated or patchy populations are at higher risk of local extinction than are those that are geographically connected because of inbreeding depression and environmental perturbation (McKinney 1997). Further, declining populations are at higher risk when geographically isolated from healthy populations. Thus, small environmental changes may reduce the probability of persistence of naturally isolated populations, such as endemic or rare species, or those fragmented by human activities (Slatkin 1985, Hanski and Gilpin 1997, McKinney 1997). Identifying the spatial scales at which local populations or meta-populations are connected by gene flow can indicate how subpopulations might respond in the event of local extirpation, which actions might reverse those trends, and the likelihood that habitat corridors would facilitate movement of individuals (Hughes et al. 1996, 1998). Physical and physiological barriers to dispersal between low and high elevation populations may impact local dynamics, and need to be considered when evaluating patterns of gene flow in montane species (Funk et al. 2005a).

Many Neotropical amphibian species from upland habitats in Latin America have experienced "enigmatic" sudden and dramatic 
population declines (Pounds et al. 1997, Young et al. 2001, Lips et al. 2003, Lips et al. 2004, Stuart et al. 2004, Bustamante et al. 2005). Many of which have been attributed to the fungal pathogen Batrachochytrium dendrobatidis. These declines are characterized by a sudden and massive faunal collapse in which half the species at a site decline and disappear, a few species are apparently unaffected, and a third group declines but persists at reduced numbers (Pounds et al.1997, Lips et al. 2003). An analysis of patterns of species decline among four upland sites in Costa Rica and Panama indicated that lifetime aquatic index was the most important predictor of decline, with those species having the greatest amount of contact with aquatic habitats most likely to suffer population declines (Lips et al. 2003). Declines at three of those sites were attributed to $B$. dendrobatidis and local extinctions of more aquatic species presumably reflect infection by this aquatic fungus. Endemic species and those with restricted elevational ranges were also more likely to experience declines, presumably because of the lack of population connectivity and potential for recolonization from outside of affected areas (Lips et al. 2003). All glassfrogs (Family Centrolenidae) are obligatory riparian species and are expected to be susceptible to $B$. dendrobatidis and to decline in numbers. However, some species such as Centrolene prosoblepon (Boettger, 1892) have a broad elevational and geographic range (0-2 $700 \mathrm{~m}$; Duellman 1999) which should allow recolonization, as supported by the observation that $C$. prosoblepon persists at low numbers at all four of the sites in that analysis (Lips et al. 2003).

Species like C. prosoblepon that decline but persist offer an opportunity to identify mechanisms that enable population persistence and recovery, and could inform conservation actions. For example, population persistence following a decline in amphibian abundance and diversity might indicate resistance to agents of decline (Woodhams et al. 2003, Retallick et al. 2004), or recolonization by individuals from unaffected areas (Lowe 2003, Funk et al. 2005a). These two mechanisms dictate very different research and conservation priorities: the first suggests further immunological or epidemiological research; the second stresses the importance of habitat conservation, restoration, and/or species reintroductions.

Understanding patterns of directional movement is also important to predict how a riparian frog species will persist in increasingly fragmented landscapes (reviewed by Lowe 2003, Funk et al. 2005b). Movement within a watershed is constrained by the connectivity of tributaries for fully aquatic organisms (e.g., fish, crustaceans); however for stream anurans and invertebrates with biphasic life stages (aquatic larval and terrestrial adult), overland movement among adjacent streams is possible and likely contributes to gene flow among watersheds (Hughes et al. 1996, Lowe 2003).

Mark-recapture studies are useful for providing detailed information on individual movement patterns over short periods, but conclusions about historical connectivity among populations, the impact of habitat fragmentation on dispersal, and quantifying rare long distance dispersal are difficult to measure using field techniques alone (Tallmon et al. 2000, Watts et al. 2004, Funk et al. 2005a). Molecular estimates of gene flow provide a long term, evolutionary perspective of local population genetic structure and historical gene flow in local populations, but do not directly investigate the ecological and demographic factors underlying geographic structure. Combined, these approaches are powerful for evaluating the contribution of behavior, landscape, and evolutionary history in structuring populations (Tallmon et al. 2000).

We studied movement patterns for a common glassfrog, C. prosoblepon, (Centrolendiae: Anura). Several populations of this species have declined but persist at several Costa Rican and Panamanian sites (Lips, unpub.), suggesting that either recolonization or resistance enables this species to survive local perturbations. We measured movement patterns of males and indirectly estimated female-mediated movement through molecular genetics to test the hypothesis that either short or long-term dispersal linked populations within and among watersheds. 


\section{MATERIALS AND METHODS}

C. prosoblepon is a small $[\bar{x} \pm \mathrm{SD}$ mass (males, $\mathrm{N}=219)=0.9 \pm 0.11 \mathrm{~g}$; snout-ventlength $(\mathrm{SVL}$, males $\mathrm{N}=219)=25.15 \pm 1.5 \mathrm{~mm}]$ stream-breeding frog widely distributed from Nicaragua to Ecuador in moist premontane and montane forests (Duellman 1999, Savage 2002). Males can be found calling year-round on leafy plants along forested streams (Ibáñez et al. 1999). Females are found sporadically along the streams where they deposit clutches of 10-40 eggs $(\bar{x}=24 \pm 6.0$; Lips, unpublished) in moss and on leaf tops overhanging the streams. Hatching tadpoles drop into the stream where they congregate in leaf packs and soft sediments (Villa and Valerio 1982, McDiarmid and Altig 1999). Males exhibit site fidelity and actively defend their territories from other males by engaging in combat using specialized humeral hooks (Jacobson 1985).

We studied gene flow in C. prosoblepon at a cloud forest site in Parque Nacional G.D. Omar Torríjos Herrera, El Copé, Provincia Coclé, Panama (UTM 957,946 N 544,820 E, Zone 17). This 25000 ha national park is centered on the Continental Divide, and includes both Caribbean and Pacific drainages; our site is located at the eastern end of the Cordillera Central at elevations between 600 and $700 \mathrm{~m}$. Mean annual temperature is $\sim 22{ }^{\circ} \mathrm{C}$, and mean annual rainfall averages $\leq 3000 \mathrm{~mm}$, with a distinct rainy season extending from May to early December (Lips, unpub.). Portions of this park were selectively logged in the late 1970's (A. Jaslow, pers. com.), and a network of tributaries dissects the resulting matrix of secondary forest. All streams are small (0-40 cm deep and 0.2-5.5 m wide), swiftly flowing, and characterized by dense overhanging vegetation (Lips, unpub.). We conducted a mark-recapture study in each of four headwater stream transects belonging to the same drainage network: Loop Stream (LO), Río Guabal (GU), Cascada (CA) and Silenciosa (SI). All transects were separated by at least $200 \mathrm{~m}$ of stream except CA which was separated from GU by only $40 \mathrm{~m}$. We flagged each transect every $20 \mathrm{~m}$ to identify frog position (m) along transect. Additionally, we marked individuals along two additional streams within the study area (Fenomenal (FE) and Spacer (SP). FE is tributary stream of GU whereas SP is a $100 \mathrm{~m}$ extension of LO; these individuals were not included in the mark-recapture study but were used for genetic estimates and for among-stream movement. To broaden the spatial scale of our analyses of gene flow to $2.5 \mathrm{~km}^{2}$ and $5.0 \mathrm{~km}^{2}$ we sampled additional streams in the Atlantic watershed, Treinta (350 m elevation; TR) and La Rica (126 m elevation; LA).

\section{Field Sampling}

Mark-recapture studies. During 20002002 we conducted mark-recapture on adult male C. prosoblepon for estimates of movement distance, frequency, and direction. Over the course of 28 weeks during the wet season in each year we individually toe-clipped frogs along a $200 \mathrm{~m}$ transect in each of four headwater stream transects: $\mathrm{LO} ; \mathrm{n}=23, \mathrm{GU}$; $\mathrm{n}=19, \mathrm{CA} ; \mathrm{n}=22, \mathrm{SI} ; \mathrm{n}=20$. Additionally, we marked 18 individuals along $\mathrm{FE}$ and 15 individuals along SP.

At approximately four $d$ intervals over each three mo field season (June to August) we conducted nocturnal surveys on each transect using visual and acoustic cues to locate frogs (Heyer et al. 1994). We captured individuals by hand and marked them with a unique toe clip combination. Toe clips were stored in vials with $95 \%$ ethanol for subsequent genetic analyses. For each individual we recorded sex, date and time of capture, distance along transect, SVL, and mass. Males were identified by the presence of humeral hooks; females were identified by a reduced or absent humeral hook or by eggs visible in the abdominal region. Eight voucher specimens were deposited in the Fluid Vertebrate Collection at Southern Illinois University, Carbondale (SIUC H06940-47, H06949).

We measured movements of adult males only because captures of adult females and juveniles are rare, and tadpoles are difficult to 
mark and follow in the field. We calculated individual distance moved as the straight-line distance between the initial and final capture locations, and for individuals recaptured multiple times, we used the maximum distance between any two localities. We report recapture rates and movements for three-three mo periods $(2000,2001,2002)$, two one year periods (2000-2001, 2001-2002) and one two year period (2000-2002). Using Kruskal-Wallis nonparametric analysis of variance tests we compared movement distances and frog density among streams to test for density dependent movement. We also determined whether the mean directional distances (upstream or downstream) traveled by males differed among streams.

Gene flow estimates. In 2000, we collected toe clips from marked individuals along all four stream transects, and from four additional, more distant streams (where we did not conduct mark-recapture estimates) for an hierarchical analyses of gene flow. Our estimates of gene flow at $1.2 \mathrm{~km}^{2}$ encompass the four mark-recapture transects plus FE. To assess the movement of individuals over a mountain range, we included individuals from the Río Colorado $(\mathrm{CO} ; \mathrm{n}=3)$ of the Pacific drainage across the Continental Divide. For gene flow estimates at $2.5 \mathrm{~km}^{2}$ and $5 \mathrm{~km}^{2}$, we included samples collected over five d in 2000 from Quebrada Treinta (TR; $n=3$ ) and Quebrada La Rica (LA; $n=3)$, respectively.

\section{Laboratory}

We isolated total genomic DNA from toe tips using the QIAGEN DNeasy Kits (QIAGEN, Valencia, CA). We amplified a $1.5 \mathrm{~kb}$ fragment that included the complete mitochondrial NADH dehydrogenase subunit 1 (ND1) gene and portions of the $16 \mathrm{~S}$ ribosomal RNA gene (rRNA), leucine transfer RNA gene (tRNA) and isoleucine tRNA gene. We used the primers 16S-frog (5'-TTACC CTRGGGATAACAGCGCAA-3') and H4419 (Macey et al. 1998); these primers correspond to nucleotide positions 4 415-4 437 and 5 927-5 946, respectively, in Xenopus laevis (GenBank Accession number NC-001573; Roe et al. 1985). Amplification reactions were conducted in a final reaction volume of $50 \mu \mathrm{l}$ containing: $20 \mathrm{ng}$ genomic DNA, $5.0 \mu \mathrm{l}$ of 10X PCR buffer, $200 \mu \mathrm{M}$ of each dNTP, 0.5 $\mu \mathrm{M}$ each primer, $2.0 \mathrm{mM} \mathrm{MgCl}{ }_{2}$, and $1.0 \mathrm{U}$ of Taq polymerase. Amplification profile included an initial denaturing at $94{ }^{\circ} \mathrm{C}$ for one minute, followed by 35 cycles of denaturing at $94{ }^{\circ} \mathrm{C}$, annealing at $56{ }^{\circ} \mathrm{C}$, and extension at $72{ }^{\circ} \mathrm{C}$ for one minute each, and a final extension of 72 ${ }^{\circ} \mathrm{C}$ for 5 minutes. PCR products were electrophoresed on a $1 \%$ TAE agarose gel, excised from the gel, and purified using QIAquick Gel Extraction $\mathrm{Kit}^{\mathrm{TM}}$ (QIAGEN, Valencia, CA) before sequencing.

We obtained DNA sequences with manual sequencing; we designed a species-specific internal primer, frog-ILE ( 5 ' -ATTA GGA GGCGA GGGGGT T T GAAC-3'), located in the tRNA isoleucine gene. The primer was end labeled with $\gamma{ }^{32} \mathrm{P}$ dATP using $\mathrm{T}_{4}$ polynucleotide kinase. Sequences were generated with the Promega $^{\mathrm{TM}}$ fmol DNA Sequencing System and resolved on a $42 \mathrm{~cm} 6 \%$ denaturing polyacrylamide gel run at 1500 Volts for 2 to $5.5 \mathrm{~h}$. Autoradiograms were read manually and aligned using the ClustalW option in MacVector 6.5.3 (Oxford Molecular Group, San Francisco, California, 1999).

Genetic Analyses. We used Analysis of Molecular Variance (AMOVA; Excoffier et al. 1992), as implemented in Arlequin version 2.001 (Schneider et al. 2000) to estimate hierarchical levels of gene flow. We partitioned genetic variance among the three groups of streams $\left[\phi_{\mathrm{CT}} ; \mathrm{LA}, \mathrm{CO}\right.$, and six headwater streams (LO, CA, FE, GU, SI, TR)], among six headwater streams $\left(\phi_{\mathrm{SC}}\right)$, and among individuals from all groups $\left(\phi_{\mathrm{ST}}\right)$. All population pairwise differences were tested for significance $(\alpha=0.05)$ by comparisons with 1000 nonparametric random permutations. Pairwise estimates of gene flow were used to assess the genetic differentiation of Caribbean headwater streams to the one 
Pacific (CO) stream population across the continental divide. Unique nucleotide sequences (haplotypes) were used to generate the Euclidean matrix of squared distances among all pairs of haplotypes.

We conducted a Mantel test (Miller 1999) to test for correlation between geographic distance $(\mathrm{m})$ and genetic distance (pairwise $\phi_{\mathrm{ST}}$ ) among pairs of populations using the Mantel Nonparametric Test Calculator, v. 2.00 (Leidloff 1999). Mantel tests were calculated using two different measures of geographic distance; the first assumed that individuals move along stream corridors (stream distances) and the second considered the possibility of overland movement (overland distances). Pairwise geographic distances were measured as either the distance between two captures along stream corridors or the shortest distance $(\mathrm{m})$ between two streams (but not corrected for topographic relief) and tested for significance with 1000 permutations.

To compare the result of the mark-recapture study with indirect estimates of gene flow, we estimated effective population sizes $\left(\theta=2 \mu \mathrm{N}_{\mathrm{F}}\right)$ within each sample location as well as migration rates $\left(\mathrm{M}=2 \mathrm{mN}_{\mathrm{F}}\right)$ among all pairs of sample locations using maximum likelihood estimates in Migrate 1.7.3 (Beerli and Felsenstein 2001). We used ten short chains of 5000 geneologies and three long chains of 50000 geneologies with a sampling increment of 20 geneologies. We started with a random geneology and combined chains over three runs. We used heating with four temperatures: $1,1.5,3,6$, and 12. Effective population sizes and migration rates were averaged over five independent runs.

\section{RESULTS}

\section{Mark-recapture overview}

Over a two year period we marked 314 individual C. prosoblepon on the four transects, with 745 recaptures, including individuals recaptured 1-16 times. The overall magnitude of movement was significantly biased in the upstream direction (Wilcoxon test; $\chi^{2}=31.44$, $\mathrm{df}=2, \mathrm{p}<0.001$ ), with only six individuals moving downstream from the original capture site. Six unmarked individuals were captured on forest transects up to $100 \mathrm{~m}$ away from streams, and six marked individuals changed transects over one or two years. When frogs changed transects we do not know whether those frogs moved along streams (390-1 $108 \mathrm{~m}$ ) or through the forest (250-675 m). Neither SVL (ANOVA: $\left.\mathrm{r}^{2}=0.017, \mathrm{~F}_{1,56}=0.942, \mathrm{p}=0.310\right)$ nor mass (ANOVA: $\mathrm{r}^{2}=0.012, \mathrm{~F}_{1,56}=0.643, \mathrm{p}>0.426$ ) was correlated with movements over one year.

Mark-recapture data indicate that male $C$. prosoblepon may live four years, and while individuals are capable of moving up to 1 $\mathrm{km}$, most do not move more than $10 \mathrm{~m}$ during that period (Lips, unpub.). Recapture rates were highest $(18-60 \%)$ within the three mo field seasons (Wilcoxon test; $\chi^{2}=8.18, \mathrm{df}=2$, $\mathrm{p}<0.016$ ). Our overall recapture rate for the two year period was $16 \%$, although this ranged from 5-25\% among transects (Table 1). After two years, we were still encountering frogs marked in 2000 on every transect. Over two years we recaptured $18(16 \%)$ individuals, none of which moved very much $(2.3 \pm 2.90 \mathrm{~m}$, range $=0-10 \mathrm{~m}$ ) and seven of which were found in their original location. Three frogs changed streams over two years; overland distances were 110, 300, and $725 \mathrm{~m}$, while distances along stream corridors were 180, 442, and 916 $\mathrm{m}$. Six additional males changed streams over one year; distances averaged $375 \mathrm{~m}$ for overland, and $690 \mathrm{~m}$ for corridors.

Individual male movements were similar across sampling intervals (Wilcoxon test; $\chi^{2}=3.88, \mathrm{df}=2, \mathrm{p}<0.143$ ). During the three mo intervals, frogs moved $5.69 \mathrm{~m}$ on average (range 0-108 m). Over a one year period, frogs moved $5.85 \mathrm{~m}$ on average ( $4.84 \mathrm{~m}$ in $2000-2001$, $6.95 \mathrm{~m}$ in 2001-2002), with a range of 0-45 $\mathrm{m}$ (Fig. 1). Individuals recaptured after two years moved an average distance of $2.33 \mathrm{~m}(0-10 \mathrm{~m})$ from their initial capture sites (Table 1). 
TABLE 1

Movement distances and recapture rate for $\mathrm{C}$. prosoblepon at four focal streams

Year Recaptured

\begin{tabular}{|c|c|c|c|c|c|c|c|c|c|}
\hline & & $\begin{array}{r}200 \\
n=1\end{array}$ & & & $\begin{array}{c}200 \\
n=\end{array}$ & & & $\begin{array}{r}200 \\
n=1\end{array}$ & \\
\hline & St. & $R R$ & Dist. & St. & $R R$ & Dist. & St. & $R R$ & Dist. \\
\hline & $\mathrm{GU}$ & 43 & 3.6 & GU & 10 & 12.0 & GU & 5 & 0.0 \\
\hline & $\mathrm{CA}$ & 50 & 13.5 & $\mathrm{CA}$ & 21 & 3.7 & $\mathrm{CA}$ & 25 & 2.0 \\
\hline 2000 & LO & 52 & 7.1 & LO & 32 & 4.0 & LO & 20 & 2.8 \\
\hline & SI & 24 & 1.8 & SI & 15 & 6.3 & SI & 5 & 2.0 \\
\hline & & 7.76 & & & 4.84 & 21) & & 2.33 & \\
\hline & & & & GU & 23 & 6.0 & $\mathrm{GU}$ & 23 & 10.0 \\
\hline & & & & CA & 7 & 1.5 & $\mathrm{CA}$ & 30 & 4.9 \\
\hline 2001 & & & & LO & 23 & 1.8 & LO & 35 & 4.7 \\
\hline & & $\mathrm{X}$ & & SI & 27 & 2.5 & SI & 20 & 16.3 \\
\hline & & & & & 2.8 & & & 6.95 & \\
\hline & & & & & & & $\mathrm{GU}$ & 42 & 19.6 \\
\hline & & & & & & & $\mathrm{CA}$ & 67 & 2.7 \\
\hline 2002 & & & & & & & LO & 64 & 3.9 \\
\hline & & $X$ & & & X & & SI & 53 & 2.0 \\
\hline
\end{tabular}

Recapture rate (RR \%) and average movement distance (Dist.; $\mathrm{m}$ ) for each stream (see text for abbreviations) over three temporal scales: 3-4 months, 1 year and 2 years. Recapture rate (\%) and average movement distance (range) for all streams within each block are combined and presented in bold.

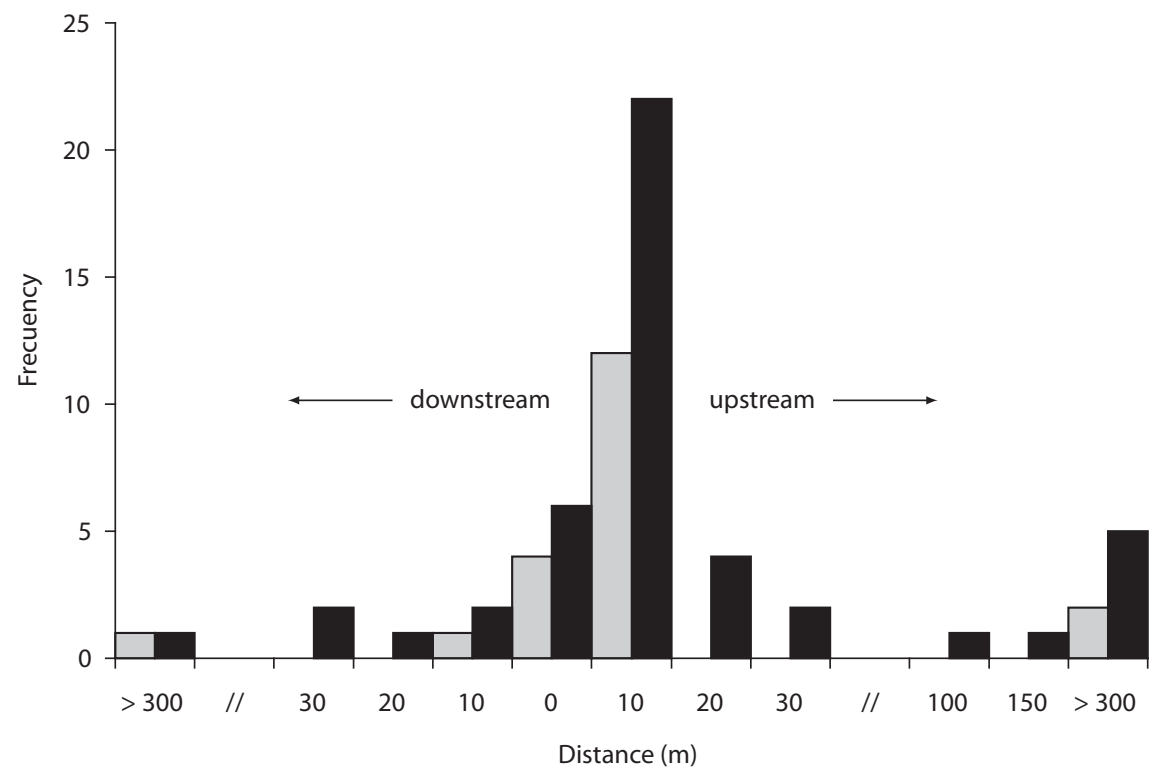

Fig. 1. Direction and frequency of movement patterns for C. prosoblepon at El Copé, Panama. The direction and average maximum movement distance $(\mathrm{m})$ of individuals recaptured after one (black bars) and two (gray bars) years and were pooled for four focal streams. All individuals that moved between transects are included in the $>300 \mathrm{~m}$ category. 
Yearly variation in movement. In 2000, we conducted 29 surveys on the four transects, with 232 capture events (219 males and 13 females). During our 11 week field season, we marked 109 individuals and recaptured 51 (47\%) of these (49 males and two females). Mean male movement was 7.76 m (mode $=0 \mathrm{~m}$ ) over 14 weeks (Table 1 ); $75 \%$ of all recaptured individuals moved less than $4 \mathrm{~m}$ on average (range $=0-75 \mathrm{~m}$ ). We did not detect movements among transects during this time. We marked 12 and 21 individuals on SP and FE transects, respectively. We did not revisit these stream transects after 2000, but recaptured some of these individuals on other transects in subsequent years.

In 2001 our 25 surveys resulted in 253 capture events (226 males, 26 females and one juvenile) and we marked 81 new individuals. During this 6 week field season we recaptured 25 (31\%; Table 1) of these newly marked frogs. Mean male movement was $2.8 \mathrm{~m}$ (Table 1). One male changed transects, moving 300-456 m over 6 weeks $(\sim 10 \mathrm{~m} / \mathrm{d})$.

In 2002, we conducted 32 surveys, marking 124 new individuals in 476 capture events (442 males, 32 females). Over the 11 week field season, we recaptured 74 (60\%; Table 1) of these newly marked frogs. Mean male movement for newly marked frogs was $4.87 \mathrm{~m}$ (range $=0-108$; Table 1 ). One male changed transects, moving from SI to CA over $12 \mathrm{~d}$, a distance of at least $700 \mathrm{~m}$ if movement occurred along the stream $(\sim 58 \mathrm{~m} / \mathrm{d})$.

Density, measured as the total number of marked individuals per transect, varied among streams, but was not correlated with movement patterns. Annual density for the entire study area was higher in 2002 than in 2000 or 2001 (Wilcoxon test; $\chi_{2}{ }_{2}=4.68, \mathrm{p}=0.09$ ). Only CA showed variation among years $\left(\chi_{2}^{2}=10.682\right.$, $\mathrm{p}<0.005)$. Frog density was greatest on LO during the 2000 and 2001 field seasons $(\bar{x}$ $=1 \mathrm{frog} / 11 \mathrm{~m}$ and 1 frog $/ 12 \mathrm{~m}$ respectively) as compared to other transects (Wilcoxon tests; $\chi_{3}^{2}=14.24, \mathrm{p}<0.003$ and $\left.\chi_{3}^{2}=19.05, \mathrm{p}<0.001\right)$. In 2002, LO and CA had higher mean densities ( 1 frog/11 $\mathrm{m}$ and 1 frog/9.4m, respectively) as compared to GU and SI (Wilcoxon test; $\left.\chi_{3}^{2}=18.52, \mathrm{p}<0.003\right)$.

\section{Gene flow}

Partial ND1 sequences of 220 base pairs (bp) from 110 individuals revealed five polymorphic sites and six unique haplotypes (Table 2). Unique haplotypes have been deposited in GenBank under accession numbers AY 286057-59, 286062, 286066, 286070, 578735-38. At the fine and intermediate scales, maximum sequence divergence among haplotypes was $1.36 \%$, with all five substitutions

TABLE 2

Numbers of haplotypes (Hap) observed for C. prosoblepon at fine spatial scales $\left(1.2-5 \mathrm{~km}^{2}\right)$

$\begin{array}{cccccccc}\text { Location } & \text { Hap 1 } & \text { Hap 2 } & \text { Hap 4 } & \text { Hap } 8 & \text { Hap 9 } & \text { Hap 10 } & \text { Total } \\ \text { LA } & 0 & 0 & 0 & 3 & 0 & 0 & 3 \\ \text { CO } & 0 & 0 & 3 & 0 & 0 & 0 & 3 \\ \text { LO } & 0 & 3 & 16 & 4 & 0 & 0 & 23 \\ \text { GU } & 0 & 0 & 14 & 3 & 1 & 1 & 19 \\ \text { CA } & 1 & 3 & 14 & 1 & 1 & 1 & 21 \\ \text { SI } & 1 & 0 & 14 & 2 & 1 & 2 & 20 \\ \text { FE } & 0 & 0 & 17 & 1 & 0 & 0 & 18 \\ \text { TR } & 0 & 0 & 3 & 0 & 0 & 0 & 3 \\ \text { Total } & 2 & 6 & 81 & 14 & 3 & 4 & 110\end{array}$


occurring as synonymous changes. Because individuals of $C$. prosoblepon are generally restricted to streamside habitats (Ibáñez et al. 1999), we assumed a one-dimensional stepping stone model. Because larval mortality is typically high in anurans (McDiarmid and Altig 1999) and the breeding season is year round (Brenes, pers. comm.), we assumed that adults were not siblings. Pairwise comparisons of $\phi_{\mathrm{ST}}$ for all transects ranged from 0.00 to 0.025 and were statistically significant only between FE and LO (Table 4). Gene flow was high and subpopulations homogenous within the $2.5 \mathrm{~km}^{2}$ area between TR and the headwater streams along the elevation gradient
$\left(\phi_{\mathrm{SC}}=0.007, \mathrm{p}=0.325\right.$; Table 3$)$. Most individuals $(86 \%)$ exhibited either Haplotype 4 or 8 , and every haplotype was found in at least two streams (Table 2).

We found preliminary evidence indicating that gene flow is potentially restricted between Caribbean lowland populations and headwater streams. All three samples from the lowland population contained Haplotype 8, which occurred in $13 \%$ of frogs from headwater streams (Table 2). The estimated $\phi_{\mathrm{CT}}$ among groups was $0.322(\mathrm{p}=0.065)$ and $\phi_{\mathrm{ST}}$ among populations was $0.327(\mathrm{p}=0.033$; Table 3$)$. We are cautious to claim that gene flow is definitely restricted at this scale because statistical

TABLE 3

Hierarchical analysis of molecular variance (AMOVA) estimates of gene flow in populations of $\mathrm{C}$. prosoblepon

$\begin{array}{ccccccc}\begin{array}{c}\text { Source of } \\ \text { Variation }\end{array} & \begin{array}{c}\text { Scale of } \\ \text { Analyses }\end{array} & \text { d.f. } & \begin{array}{c}\text { Variance } \\ \text { components }\end{array} & \text { \% of variance } & \text { Fixation index }(\phi) & P \\ \phi_{\mathrm{CT}} & 5.0 \mathrm{~km}^{2} & 2 & 0.1334 & 32.36 & 0.322 & 0.065 \\ \phi_{\mathrm{SC}} & 2.5 \mathrm{~km}^{2} & 5 & 0.0021 & 0.53 & 0.007 & 0.325 \\ \phi_{\mathrm{ST}} & 5.0 \mathrm{~km}^{2} & 102 & 0.2776 & 67.21 & 0.327 & 0.033 \\ \text { Total } & -- & 109 & 0.4131 & -- & -- & --\end{array}$

Significance tested at each level by computations with 1000 permutations (Excoffier et al. 1992). $\phi_{\mathrm{CT}}=$ among three groups: LA, CO, and 6 headwater streams (GU, LO, CA, SI, FE, TR), $\phi_{\mathrm{SC}}=$ among subpopulations within headwater streams, $\phi_{\mathrm{ST}}$ $=$ among individuals within all subpopulations.

TABLE 4

Population pairwise estimates of $\phi_{S T}$ (bottom diagonal) and geographic distance along streams ( $m$ ) (top diagonal) for C. prosblepon at fine and intermediate spatial scales

$\begin{array}{ccccccccc} & \text { LA } & \text { CO } & \text { LO } & \text { GU } & \text { CA } & \text { SI } & \text { FE } & \text { TR } \\ \text { LA } & - & 4,200 & 4,940 & 4,500 & 4,550 & 4,890 & 4,350 & 2,500 \\ \text { CO } & 1.000 & - & 535 & 690 & 485 & 760 & 450 & 2,700 \\ \text { LO } & 0.380^{*} & -0.012 & - & 240 & 355 & 150 & 670 & 2,440 \\ \text { GU } & 0.587^{*} & -0.142 & 0.025 & - & 15 & 190 & 230 & 2,000 \\ \text { CA } & 0.347^{*} & -0.099 & -0.032 & -0.009 & - & 320 & 315 & 2,050 \\ \text { SI } & 0.512^{*} & -0.147 & 0.035 & -0.045 & -0.009 & - & 620 & 2,390 \\ \text { FE } & 0.897^{*} & -0.195 & 0.117^{*} & -0.002 & 0.055 & 0.007 & - & 1,850 \\ \text { TR } & 1.000 & 0.00 & -0.012 & -0.142 & -0.099 & -0.147 & -0.195 & -\end{array}$

Stream distance approximated using tape measure and topographic map. See text for stream abbreviations. Negative $\phi_{\mathrm{ST}}$ values are not significantly different from zero.

$* \mathrm{p}<0.05$ 
power was limited because of low sample sizes $(n=3)$ from the LA population. Nonetheless, six of 28 pairwise estimates of $\phi_{\mathrm{ST}}$ were nominally significant $(\mathrm{p}<0.05$, Table 4). The Mantel test for isolation by distance was not significant using either stream $(\mathrm{g}=2.451, \mathrm{p}<0.05)$ or overland distance $(\mathrm{g}=2.1707, \mathrm{p}<0.05)$, but this is likely due to the small sample size and shared haplotypes found in TR and LA.

A matrix of pairwise estimates of migration $\mathrm{Nm}_{\mathrm{F}}$, (Table 5) suggested considerable gene flow among headwater sites, and limited gene flow between LA and headwater streams. Each headwater stream was connected to at least one other subpopulation by one or more female migrants and one or more female emigrants each generation with the exception of the LA sample, which received migrants but did not contribute to any other population. This may be interpreted as an indication of a lack of upstream gene flow in this population of C. prosoblepon, although since the LA sample was so small, this is far from robust.

\section{DISCUSSION}

We provide an estimate of population genetic differentiation for a small, territorial, stream-breeding frog that has suffered population declines throughout its range (Lips et al. 2003, Bustamante et al. 2005). Stream subpopulations of $C$. prosoblepon at El Copé are genetically homogenous within our $1.2 \mathrm{~km}^{2}$ study area, with potential genetic subdivision and restricted gene flow at $5.0 \mathrm{~km}^{2}$. Markrecapture data indicate that male $C$. prosoblepon may live four years, and while individuals are capable of moving up to $1 \mathrm{~km}$, most do not move more than $10 \mathrm{~m}$ during that period indicating that movement distance is not regulated by density dependence. Movement did not significantly vary among streams. This study was conducted prior to the population declines that occurred at this site in 2004 (Lips, unpub.) and offers an opportunity to examine natural movement patterns at a spatial scale equivalent to the recolonization potential for this species. The strength of this study lies in the complementary analyses of demographic and genetic data that yielded a comprehensive view of local processes structuring populations for a tropical riparian frog. Published population level estimates of gene flow in anurans are represented by a few studies of species with a great diversity in reproductive modes, habitats, ecologies, and life history traits, yet most estimates of population differentiation fell within $\sim 10 \mathrm{~km}$, suggesting dispersal capacity may be relatively low in many anurans. While most anurans exhibit

TABLE 5

Estimates of effective population size $\left(n_{e} m \mu\right)$ and pairwise estimates of migration $\left(N_{f} m\right)$ for C. prosoblepon populations at fine and intermediate spatial scales

\begin{tabular}{cccccccccc}
$\begin{array}{c}\text { Source } \\
\text { Population }\end{array}$ & \multicolumn{7}{c}{$\mathrm{N}_{\mathrm{F}} \mathrm{m}$ in Receiving Population } \\
& $\mathrm{N}_{\mathrm{e}} \mathrm{m} \mu$ & $\mathrm{LA}$ & $\mathrm{CO}$ & $\mathrm{LO}$ & $\mathrm{GU}$ & $\mathrm{CA}$ & $\mathrm{SI}$ & $\mathrm{FE}$ & $\mathrm{TR}$ \\
$\mathrm{LA}$ & 0.0033 & - & 0.132 & 0.032 & 0.000 & 0.000 & 0.056 & 0.000 & 0.032 \\
$\mathrm{CO}$ & 0.0043 & 0.217 & - & 0.247 & 0.014 & 0.000 & 0.000 & 0.000 & 2.816 \\
$\mathrm{LO}$ & 0.0046 & 0.863 & 1.846 & - & 0.083 & 0.105 & 0.426 & 2.442 & 0.787 \\
$\mathrm{GU}$ & 0.0047 & 2.316 & 2.503 & 0.118 & - & 2.531 & 2.537 & 0.269 & 6.542 \\
$\mathrm{CA}$ & 0.0061 & 0.275 & 4.285 & 4.820 & 1.880 & - & 13.080 & 0.960 & 3.325 \\
$\mathrm{SI}$ & 0.0060 & 1.227 & 3.123 & 1.052 & 7.175 & 9.001 & - & 1.210 & 2.224 \\
FE & 0.0052 & 0.411 & 9.727 & 0.000 & 1.505 & 0.272 & 0.000 & - & 3.636 \\
$\mathrm{TR}$ & 0.0051 & 0.015 & 0.000 & 0.018 & 0.120 & 0.000 & 0.000 & 1.872 &
\end{tabular}


strong genetic differentiation over broad geographic scales (30-250 km), (e.g., Shaffer et al. 2000, Newman and Squire 2001, Nielson et al. 2001, Crawford 2003, Funk et al. 2005a), there are no consistent trends among published studies at spatial scales less than $10 \mathrm{~km}$. Some studies have shown population genetic differentiation at moderate scales (ca. $5 \mathrm{~km}$ ), such as that found in C. prosoblepon (this study), Eleutherodactylus cooki (Burrowes and Joglar 1999), Litoria pearsoniana (McGuigan et al. 1998), Physalaemus pustulosus (3 km; Lampert et al. 2003) and Bufo canorus (Shaffer et al. 2000). Other studies found weak genetic differentiation at 4.3 and $10.5 \mathrm{~km}$ (Eleutherodactylus stejnegerianus; Crawford 2003). In contrast to genetic homogeneity observed in our study at $1.2 \mathrm{~km}^{2}$, some species exhibit genetic differentiation over distances as little as $50 \mathrm{~m}$ (Geocrinia rosea; Driscoll 1998), and $1 \mathrm{~km}$ (Rana sylvatica; Squire and Newman 2002). Because there are relatively few studies of the population genetic structure for most amphibians, and especially for the critically endangered neotropical fauna (Stuart et al. 2004), additional dispersal and genetic data for other species are needed before conclusions regarding species specific responses to enigmatic population declines are possible. However, the rapidity of these losses demands increased studies of population genetics to devise effective captive breeding programs and protected areas to ameliorate those losses.

In many stream-dwelling organisms, limited dispersal results in population genetic structure reflecting the hierarchy of the drainage network (Hughes et al. 1995, 1996, Wishart and Hughes 2001) whereas overland dispersal (e.g., by winged invertebrates) results in greater genetic homogeneity within and among watershed populations (Tasiagma ciliata; Hughes et al. 1998). Contrary to our original assumptions that $C$. prosoblepon moved only along riparian corridors, we found several males in forest, away from streams and our direct mark-recapture study identified several males who moved among stream transects, suggesting the possibility of overland movement. Our gene flow estimates of movement also indicate widespread movement among headwater stream populations. Generally, an exchange of one migrant per generation among populations is sufficient to prevent loss of intra-population genetic variation while migration by ten or more individuals is sufficient to prevent any detectable genetic divergence among populations (Mills and Allendorf 1996).

The extent to which mountain ranges act as a barrier directly relates to the physiological limits of the species (elevational range, tolerance to desiccation; Funk et al. 2005a,b). Despite high dispersal capacity of some anurans, mountain ranges may isolate populations of some species (Rana luteiventris, 5.75 km, Funk et al. 2005a, Lougheed et al. 1999), but not others (E. stejnegerianus; Crawford 2003). Such disparities likely reflect differences in ecology among species. Movement between watersheds for $C$. prosoblepon at this site is likely facilitated by the low elevation of the continental divide $(800 \mathrm{~m})$, which is well within the elevation range of the species.

Long distance movement by males is clearly important in connecting headwater stream populations, but significant female contributions are predicted in this mating system characterized by male philopatry and the asynchronous arrival of females to the breeding site (e.g., Austin et al. 2003, Greenwood 1980).

Our data for this population of C. prosoblepon are also consistent with patterns seen in the colonization cycle of aquatic invertebrates, in which headwater populations persist because upstream movements of adults compensate for downstream drift of larvae (Müller 1982). This pattern is probably common in many riparian amphibians, but has only been reported for $C$. prosoblepon and the spring salamander Gyrinophilus porphyriticus, in which upstream adult movement offset downstream larval drift (Lowe 2003). Although we did not document downstream larval drift (Müller 1982, Lowe 2003), headwater streams at El Copé are periodically scoured by floods (Ranvestel et al. 2004) which displace substrates, insects, and tadpoles. We found large aggregations of 
centrolenid tadpoles in deep pools throughout these streams (Brenes and Lips, unpub.), indicating short distance movements away from oviposition sites.

Our data suggest that $C$. prosoblepon is capable of long distance and upstream movements, and that populations are connected within and between adjacent watersheds. This dispersal capacity has important conservation consequences as it indicates that recolonization of upland sites affected by declines by individuals from unaffected lowland populations may be possible. C. prosoblepon was once very common at the Reserva Forestal Fortuna in western Panama with up to 24 individuals per $300 \mathrm{~m}$ transect (Lips, unpub.). During a catastrophic die-off at that site in 1996 (Lips 1999), KRL found six dead or dying C. prosoblepon and captured only a few individuals of this species in each subsequent year. Abundance remained extremely low until 2000 when she encountered 32 individuals in 32 riparian surveys (1 frog/333 m; unpub.). In a similar situation, local abundances of male $C$. prosoblepon was as high as $4.4 / \mathrm{m}$ in Monteverde, Costa Rica (Jacobson 1985) until the late 1980 's when many anuran populations declined at this site. Fifteen years postdeclines $C$. prosoblepon persists at $<1$ frog/12 m (Pounds et al. 1997), but four populations are increasing at this site, three of which occur near potential source populations at lower elevations (Pounds et al. 1997).

Riparian corridors are often neglected in forest and wetland conservation plans (Pringle, 2001) yet these corridors may be critical in maintaining population dynamics of particular riparian species, and maintaining connectivity between lowland and headwater streams within a watershed (Vannote et al. 1980, Hughes et al. 1998). Many pond-breeding frogs exhibit metapopulation structure and depend on dispersal among subpopulations for persistence (Berven and Grudzien 1990, Sjögren 1991, Alford and Richards 1999). To our knowledge, this is one of only two population genetic studies of Neotropical stream-breeding anurans (Burrows and Joglar 1999). Over one-third of
Neotropical amphibian species have suffered from population declines and many of these are stream-breeding species (Stuart et al. 2004). Additional population genetic studies of other Neotropical frog species, combined with direct measures of both male and female movement patterns, will inform our efforts to predict colonization abilities. For example, species with high colonization potential will likely persist naturally, provided that riparian and forest corridors are preserved and protected, whereas species which exhibit low dispersal capacity and high population structure at fine scales, are at higher risk for local extinction. These species are a conservation priority, and efforts such as captive breeding programs, may be required to ensure the survival of extirpated populations.

\section{ACKNOWLEDGMENTS}

This work was funded by ASIH Gaige Award for Graduate Research, SIUC University Professional Women's Association, the SIUC Department of Zoology (to JMR), the National Science Foundation (DEB \# 9977063 and 0213851) and the Bay and Paul Foundation (to KRL). Thanks to staff of the Smithsonian Tropical Research Institute and Parque Nacional Omar Torríjos Herrera for support and assistance. All research and collecting permits were approved by Autoridad Nacional del Ambiente of Panama (ANAM Permits \#0899, 0900, 1189, 15313, 06202, 04202, 03201, 06101, 02500, 075000) and the SIUC Animal Care Committee (protocol \# 00-004). We thank curators at MVZ and LSUMNS for loans of tissue; T. Reeder who provided unpublished primer information; D. Drake, A. Novas, S. Novas, R. Rossmanith, M. Ryan, A. Ranvestel, and L. Witters for field assistance; F. Anderson, E. Dopman, D. Keeney, R. Macey, and A. Schrey for laboratory and analytical assistance. Many people contributed significantly to earlier drafts, especially G. Adams, L. Chan, J. Fox, M. Vellend, C. Vriesendorp, K. Zamudio and two anonymous reviewers. 


\section{RESUMEN}

La capacidad de dispersión determina y mantiene el flujo genético local, y esto tiene implicaciones para la persistencia poblacional y/o la recolonización que sigue a perturbaciones ambientales. Examinamos patrones individuales de movimiento y flujo genético entre subpoblaciones de Centrolene prosoblepon (Anura: Centrolenidae) en un sitio de elevación media en El Copé, Panamá. Medimos directamente el movimiento de los machos durante un estudio de marcado-recaptura, e indirectamente con estimaciones de flujo genético a partir de secuencias de ADN mitocondrial (mtDNA). Los individuos mostraron fuerte fidelidad a su lugar: por más de dos años, las ranas macho de los cuatro arroyos al inicio del río se movieron muy poco $($ promedio $=2.33 \mathrm{~m} ;$ moda $=0 \mathrm{~m}$ ). Nueve individuos cambiaron de corriente de agua en uno o dos años, moviéndose 675-1 $108 \mathrm{~m}$. Usando la secuencia genética ND1 del ADN mitocondrial, medimos el flujo genético en dos escalas espaciales: entre arroyos que originan el río $\left(2.5 \mathrm{~km}^{2}\right)$ y entre arroyos con un gradiente longitudinal en $5.0 \mathrm{~km}^{2}$. Encontramos un flujo genético alto entre los arroyos al inicio del río ( $\mathrm{f}=0.007, \mathrm{p}=0.325$ y otro más limitado en distancias mayores $(\mathrm{f}=0.322, \mathrm{p}=0.065)$.

Palabras clave: Centrolenidae, dispersión, flujo genético, marcado-recaptura, ADN mitocondrial, Neotrópico.

\section{REFERENCES}

Alford, R. \& S.J. Richards. 1999. Global amphibian declines: a problem in applied ecology. Annu. Rev. Ecol. Syst. 30: 133-65.

Austin, J.D., J.A. Dávila, S.C. Lougheed \& P.T. Boag. 2003. Genetic evidence for female-biased dispersal in the bullfrog, Rana catesbeiana (Ranidae). Mol. Ecol. 12: $3165-3172$.

Beerli, P. \& J. Felsenstein 2001. Maximum likelihood estimation of a migration matrix and effective population sizes in $\mathrm{n}$ subpopulations by using a coalescent approach. Proc. Natl. Acad. Sci. USA 98: 4563-4568

Burrowes, P.A. \& R.L. Joglar. 1999. Population genetics of the Puerto Rican cave-dwelling frog, Eleutherodactylus cooki. J. Herpetol. 33: 706-711

Berven, K. \& T. Grudzien. 1990. Dispersal in the Wood frog (Rana sylvatica): implications for genetic population structure. Evolution 44: 2047-2056.

Boettger, O. 1892. Katalog der Batrachier-Sammlung im Museum der Senckenbergischen Naturforshenden Gesellschaft in Frankfurt am Main. Von Prof. Dr. O. Boettger. Natur-Museum und Forschungs-Institut
Senckenberg. Frankfurt a.M., Druck von Gebrüder Knauer, Frankfurt.

Bustamante, M.R., S.R. Ron \& L.A. Coloma. 2005 Cambios en la diversidad en siete comunidades de Anuros en los Andes de Ecuador. Biotropica 37: 180-189.

Crawford, A.C. 2003. Huge populations and old species of Costa Rican and Panamanian dirt frogs inferred from mitochondrial and nuclear gene sequences. Molec. Ecol. 12: 2525-2540.

Driscoll, D.A. 1998. Genetic structure, metapopulation processes and evolution influence the conservation strategies for two endangered frog species. Biol. Conserv. 83: 43-54.

Duellman, W.E. 1999. Distribution patterns of amphibians in South America, p. 255-328. In W.E. Duellman (ed.). Patterns of Distribution of Amphibians: A Global Perspective. Johns Hopkins Univ., Baltimore, USA.

Excoffier, L., P.E. Smouse \& J.M. Quattro. 1992. Analysis of molecular variance inferred from metric distances among DNA haplotypes: application to human mitochondrial DNA restriction data. Genetics 131: 479-491.

Funk, W.C., M.S. Blouin, P.S. Corn, B.A. Maxell, D.S. Pilliod, S. Amish \& F. Allendorf. 2005a. Population structure of Columbia spotted frogs (Rana luteiventris) is strongly affected by the landscape. Molec. Ecol. 14: 483-496.

Funk, W.C., A.E. Greene, P.S. Corn \& F.W. Allendorf. 2005b. High dispersal in a frog species suggests that it is vulnerable to habitat fragmentation. Biology Letters 1: 13-16.

Greenwood, P.J. 1980. Mating systems, philopatry and dispersal in birds and mammals. Anim. Behav. 28: 1140-1162.

Hanski, I.A. \& M.E. Gilpin. 1997. Metapopulation biology: ecology, genetics and evolution. Academic, San Diego, CA.

Heyer, W.R., M.A. Donnelly, R.W. McDiarmid, L.C. Hayek \& M.S. Foster. 1994. Measuring and Monitoring Biological Diversity: Standard Methods for Amphibians. Smithsonian Institution, Washington D.C., USA.

Hughes, J.M., S.E. Bunn, D.A. Hurwood, S. Choy \& R.G. Pearson. 1996. Genetic differentiation among populations of Caridina zebra (Decapoda: Atyidae) 
in tropical rainforest streams, northern Australia. Freshwater Biol. 36: 289-296.

Hughes, J.M., S.E. Bunn, D.A. Hurwood \& C. Cleary. 1998. Dispersal and recruitment of Tasiagma ciliata (Trichoptera: Tasimiidae) in rainforest streams, southeastern Australia. Freshwater Biol. 39: 117-127.

Hughes, J.M., S.E. Bunn, D.M. Kingston \& D.A. Hurwood. 1995. Genetic differentiation and dispersal among populations of Paratya australiensis (Atyidae) in rainforest streams in southeast Queensland, Australia. J.N. Am. Benthol. Soc.14: 158-173.

Ibáñez, R.D., A.S. Rand \& C.A. Jaramillo. 1999. Los Anfibios del Monumento Natural Barro Colorado, Parque Nacional Soberania y Areas Adyacentes. The Amphibians of Barro Colorado Nature Monument, Soberania National Park and Adjacent Areas. Mizrachi \& Pujol, S.A. Santa Fé de Bogota, Colombia.

Jacobson, S.K. 1985. Reproductive behavior and male mating success in two species of glassfrogs (Centrolenidae). Herpetologica 41: 396-404.

Lampert, K.P., A.S. Rand, U.G. Mueller \& M.J. Ryan. 2003. Fine-scale genetic pattern and evidence for sex-biased dispersal in the túngara frog, Physalaemus pustulosus. Molec. Ecol.12: 3325-3334.

Leidloff, A. 1999. Mantel v2.0: Mantel nonparametric test calculator. Queensland University of Technology, Brisbane, Australia.

Lips, K.R. 1999. Mass mortality of the anuran fauna at an upland site in Panama. Conserv. Biol. 13: 117-125.

Lips, K.R., J. Reeve \& L. Witters. 2003. Ecological factors predicting amphibian population declines in Central America. Conserv. Biol. 17: 1078-1088.

Lips, K.R., J.R. Mendelson III, A. Muñoz Alonso, L. Canseco-Marquez \& D.G. Mulcahy. 2004. Direct evidence of declines in amphibian populations in montane southern Mexico. Biol. Conserv. 119: 555-564.

Lougheed, S.C., C. Gascon, D.A. Jones, J.P. Bogart \& P.T. Boag. 1999. Ridges and rivers: a test of competing hypotheses of Amazonian diversification using a dart-poison frog, Epipedobates femoralis. Proc. R. Soc. Lond. B. 266: 1829-1835.

Lowe, W.H. 2003. Linking dispersal to local population dynamics: a case using a headwater salamander system. Ecol. 84: 2145-2154.

Macey, R., J.A. Schulte Ii, A. Larson, Z. Fang, Y. Wang, B.S. Tuniyev \& T.J. Papenfuss. 1998. Phylogenetic relationships of toads in the Bufo bufo species group from the eastern escarpment of the Tibetan Plateau: A case of vicariance and dispersal. Mol. Phylogenet. Evol. 9: 80-87.

McGuigan, K., K. Mcdonald, K. Parris \& C. Moritz. 1998. Mitochondrial DNA diversity and historical biogeography of a wet forest-restricted frog (Litoria pearsoniana) from mid-east Australia. Molec. Ecol. 7: 175-186.

McDiarmid, R.W. \& R.A. Altig. 1999. Tadpoles: the biology of anuran larvae. Univ. Chicago, Chicago, USA.

McKinney, M. 1997. Extinction vulnerability and selectivity: combining ecological and paleontological views. Annu. Rev. Ecol. Syst. 28: 495-516.

Miller, M. P. 1999. Mantel-Struct: A program for the detection of population structure via mantel tests. J. Heredity 90: 258-259.

Mills, L.S. \& F.W. Allendorf. 1996. The one-migrant-pergeneration rule in conservation and management. Conservation Biol. 10: 1509-1518.

Müller, K. 1982. The colonization cycle of freshwater insects. Oecologia 52: 202-207.

Newman, R.A. \& R. Squire. 2001. Microsatellite variation and fine-scale population structure in the wood frog (Rana sylvatica). Molec. Ecol. 10:1087-1100.

Nielson, M., K. Lohman \& J. Sullivan. 2001. Phylogeography of the tailed frog (Ascaphus truei): implications for the biogeography of the Pacific Northwest. Evolution 55:147-160.

Pounds, J.A., M.P. Fogden, J.M. Savage \& G.C. Gorman. 1997. Test of null models for amphibian declines on a tropical mountain. Conserv. Biol. 11: 1307-22.

Pringle, C.M. 2001. Hydrologic connectivity and the management of biological reserves: a global perspective. Ecol. Appl. 11: 981-998.

Ranvestel, A.W., K.R. Lips, C.M. Pringle, M.R. Whiles \& R.J. Bixby.2004.Neotropical tadpoles influence stream benthos: evidence for the ecological consequences of decline in amphibian populations. Freshwater Biol. 49: 274-285.

Retallick, R.W.R., H. Mccallum \& R. Speare. 2004. Endemic infection of the amphibian chytrid fungus in a frog community post-decline. PloS Biology 2: 1965-1971.

Roe, B.A., D.P. Ma, R.K. Wilson \& J.F. Wong. 1985. The complete nucleotide sequence of the Xenopus laevis mitochondrial genome. J. Biol. Chem. 260: 9759-9774. 
Savage, J.M. 2002. The amphibians and reptiles of Costa Rica. A herptofauna between two continents, between two seas. The University of Chicago, Chicago, Illinois, USA.

Shaffer, B., G. Fellers, A. Magee \& S. Voss. 2000. The genetics of amphibian declines: population substructure and molecular differentiation in the Yosemite toad, Bufo canorus (Anura: Bufonidae) based on single-strand conformation polymorphism analysis (sscp) and mitochondrial sequence data. Molec. Ecol. 9: 245-257.

Schneider, S., D. Roessli \& L. Excoffier. 2000. Arlequin: A software for population genetics data analysis. Ver. 2.00. Genetics and Biometry Lab, Dept. of Anthropology, University of Geneva, Geneva, Italy.

Sjögren, P. 1991. Extinction and isolation gradients in metapopulations: the case of the pool frog (Rana lessonae). Biol. J. Linnean Soc. 42: 135-147.

Slatkin, M. 1985. Gene flow in natural populations. Annu. Rev. Ecol. Syst. 16: 393-430.

Squire, T. \& R.A. Newman. 2002. Fine-scale population structure in the wood frog (Rana sylvatica) in a northern woodland. Herpetologica 58: 119-130.

Stuart, S.N., J.S. Chanson, N.A. Cox, B.E. Young, S.L Rodriguex, D.L. Fischman \& R.W. Waller. 2004. Status and Trends of Amphibian Declines and Extinctions Worldwide. Science 306: 1783-1786.

Tallmon, D.T., Funk, W.C., W.W. Dunlap \& F.W. Allendorf. 2000. Genetic differentiation among long-toed salamander (Ambystoma macrodactylum) populations. Copeia 1: 2-35.

Vannote, R.L., G.W. Minshall, K.W. Cummins, J.R. Sedell \& C.E. Cushing. 1980. The river continuum concept. Can. J. Fish. Aq. Sci. 37: 130-137.

Villa, J. \& C.E. Valerio. 1982. Red, white and brown! Preliminary observations on the color of the centrolenid tadpole (Amphibia: Anura: Centrolenidae). Brenesia 19/20: 1-16.

Watts, P.C., J.R. Rouquette, I.J. Saccheri, J. Kemp \& D.J. Thompson. 2004. Molecular and ecological evidence for small-scale isolation by distance in an endangered damselfly, Coenagrion mercuriale. Molec. Ecol. 13: 2931-2945.

Wishart, M.J. \& J.M. Hughes. 2001. Exploring patterns of population subdivision in the net-winged midge, Elporia barnardi (Diperta: Blephariceridae), in mountain streams of the south-western Cape, South Africa. Freshwater Biol. 46: 479-490.

Woodhams, D.C., R.A. Alford \& G. Marantelli. 2003. Emerging disease of amphibians cured by elevated body temperature. Dis. Aquat. Organ. 55: 65-67.

Young, B.E, K.R. Lips, J.K. Reaser, R. Ibáñez, A.W. Salas, J.R. Cedeño, L.A. Coloma, S. Ron, E. La Marca, J.R. Meyer, A. Muñoz, F. Bolaños, G. Chaves \& D. Romo. 2001. Population declines \& priorities for amphibian conservation in Latin America. Conserv. Biol. 15: 1213-1223. 